\title{
Societal support for the educational provisions of Finnish in the Swedish school system in theory and practice
}

\section{Lasse Vuorsola ${ }^{1}$ (iD}

Received: 25 September 2017 / Accepted: 25 September 2018 / Published online: 15 October 2018 (c) The Author(s) 2018

\begin{abstract}
Language policy has an impact both on societies and on individuals, especially in contexts where negative ideologies toward minorities and minority languages may exist. A functional language policy protects a minority and allows it to develop its culture and language, while an ineffective policy might cause irreparable damage and lead to language attrition and even complete loss of language. The development of Finnish in Sweden from a language policy perspective has been fairly positive since the mid-1990s, especially when it comes to the establishment and strengthening of the legal and regulatory support in international conventions and domestic legislation. Despite these improvements there have been practical negative developments, which are symbolised in the closing down of a bilingual independent school in Gothenburg in 2016. The closing of the schools signal opposing tendencies in the treatment of Finnish in Sweden. In this paper I will examine how supranational and national language policies are implemented locally in Gothenburg and how this implementation reveals how well the policies function and what role ideologies play in the implementation. I discuss how different levels of policymaking and application contribute to the current status of the Sweden Finnish minority and Sweden Finnish as a minority language by employing Richard Ruiz's three orientations to language planning (Ruiz 1984; Hult and Hornberger 2016) in tandem with Irvine \& Gal's concept of erasure and critical discourse analysis. I exemplify how the language policies work by studying interviews and media reporting from the field. I examine how the different discourses are in conflict with each other and what ramifications these discrepancies result in.
\end{abstract}

Keywords Language policy · Critical discourse analysis · Language rights · Bilingual education · Sweden Finnish minority

Lasse Vuorsola

lasse.vuorsola@finska.su.se

1 Section for Finnish, Department of Slavic and Baltic Studies, Finnish, Dutch and German, Stockholm University, Stockholm, Sweden 


\section{Introduction}

With the Council of Europe's and UN's status-building work, linguistic rights are portrayed as human rights, which has influenced states to protect their respective minorities and their languages with language policy at least to some degree. Language policy not only governs certain aspects of social life but also, ideally, limits possible negative ideologies that may surround a specific language in a society. When it comes to the relationship between the majority language and minority languages in a state, a fair and successful language policy may be the only way to guarantee the survival of minority cultures and languages.

In 2000 Sweden ratified the Framework Convention for the Protection of National Minorities and the European Charter for Regional or Minority Languages. Five national minority languages were identified with the ratification, namely Finnish, Meänkieli, Yiddish, Romani Chib and Sámi. However, the history of these minorities and their languages in Sweden has the span of centuries. Finnish as a minority language has developed from being perceived as a migrant language with few rights within education and social affairs to becoming a national minority language with a more stable legal position. From the 1960's this status was preceded by 2-3 decades of initially increasing support for Finnish education as a home language and later in bilingual classes in the Swedish educational system, followed by a gradual loss of presence in such instruction through the 1980's and 1990's, resulting in attempts to provide bilingual education via the system of independent schools, from 1991 (Hyltenstam and Tuomela 1996; Lainio 2001; Huss and Spiliopoulou 2005).

The current situation of Sweden Finnish is marked by contradictory developments. On one hand, there are positive developments in top-down policy, such as restarting the previously discontinued teacher training at Stockholm University. This is answering to the extensive lack of teachers of Finnish that has developed since the early 1990's. There are simultaneous worrying developments that show how the minority and minority language is struggling. An event exemplifying the minority's dire state occurred when the Schools Inspectorate closed down a bilingual independent primary school in Gothenburg in December 2016 (Skolinspektionen 2016a, b). The Schools Inspectorate in Sweden is a governmental body with four main tasks: regular supervision of schools and practices within educational institutions, quality audit, investigations and decisions regarding individual complaints and issuing permits for independent schools (Skolinspektionen 2015: 8). In their report, the Schools Inspectorate criticized the Sweden Finnish school of not being able to sufficiently fulfil its duties in providing quality education according to set standards. Under critique were areas such as providing support for pupils who are not meeting their learning objectives, having a library in the school building, having the correct documentation practices, providing the pupils the correct amount of teaching in Swedish and following the correct grading procedure (Skolinspektionen 2016a). The school and its support board was unable to remedy the above mentioned problems within the given time period and was ultimately closed. The closing of the school came as a shock to the school staff, 
its support organisation, as well as the pupils and their parents. It was also shocking for people following events and discourses surrounding the field of minority language education and policy in general. The closing down of the school caused shock, despite the rather continuous story of closed down, bilingual SwedishFinnish language, independent schools. The reaction and the continuity of backlashes for such schools are reasons for the need to try to identify and describe language policies affecting such decisions.

My aim is to examine the different discourses that affect Swedish minority language education as part of the language planning process in Sweden. For this I have chosen to apply the analytical and descriptive model of Richard Ruiz's orientations (1984, see also Hult and Hornberger 2016) to language planning. In the model he identifies three orientations as language-as-problem, language-as-right and language-as-resource. In conjunction with Ruiz's orientations I will use Irvine and Gal's (1995) notion of erasure, to discuss the local implementation of language policies, since the local level is crucial in the implementation of language policies in Sweden. I will examine (1) how supranational, national language and local policies connect with Ruiz's orientations and (2) how these orientations are reflected in the implementation of the different policies that affect Sweden. The article's material consists of supranational and national policy documents as well as micro level reactions ("events") that have been collected in the spring of 2017 in the form of interviews, radio broadcasts and newspaper articles. I shall also compare the local reactions to nationwide data uncovered in an inquiry by the Swedish government (SOU 2017: 91).

\section{Theoretical framing}

Social constructivism and critical discourse analysis builds on the claim that our social existence and practices consist of and are governed by discourses, which as a notion refer to "a set of meanings, metaphors, representations, images, stories, statements and so on that in some way together produce a particular version of events" (Burr 2015: 74-75). According to Foucault discourses should be treated "as practises that systematically form the objects of which they speak" (Foucault 1972: 49). Therefore, from a social constructivist viewpoint, language policy and planning (LPP) affects a certain language not only legally but also when it comes to ideology towards that language and its relation to other languages. In other words, language policy constructs or reconstructs a discourse surrounding a language as well as legitimises it regularly in relation to other languages.

The underlying reasons for composing language policies are often to secure the status of not only a majority language but possible minority languages as well. Minority language policy construction is at its core often based on the linguistic human rights (LHR) paradigm, which aims to secure the expressive and instrumental dimensions of a subject's linguistic rights. The expressive side relates to a subject's right to express oneself linguistically and culturally while the instrumental side seeks to ensure that language does not limit subjects' possibilities of participating in societal functions (Skutnabb-Kangas 2006: 274). However, in most cases the 
LHR paradigm is supplemented with rights that exceed the scope of LHR's baseline. The LHR approach has been contested and approaches such as linguistic citizenship has been offered as an alternative, especially in post-colonial contexts. The critique of LHR is based on the claim that it offers only surface level affirmative support for minorities and languages when a more transformative type of support would be desirable (Stroud 2001: 345). According to Stroud, "[1]inguistic citizenship denotes the situation where speakers exercise control over their language, deciding what languages are, and what they may mean, and where language issues (especially in educational sites) are discursively tied to a range of social issues" (Stroud 2001: 353 [original emphasis]). This means that one of the major differences between linguistic citizenship and the LHR paradigm is that according to linguistic citizenship the speakers themselves should have more agency while the LHR paradigm relies on nation states to be in charge. In some cases, both approaches may coexist.

Language policy does not stem from a vacuum, but rather is a part of a historical continuum and is thus bound in politics and language ideology, especially in policy based on the LHR Paradigm. Policy decisions may differ considerably from each other but as a starting point there can be identified "at least three ways language planners and policy makers [...] think about language and language diversity in relation to education and society" (Hult and Hornberger 2016: 31). Ruiz calls these ways of thinking orientations:

Orientation, as it is used here, refers to a complex of dispositions toward language and its role, and toward languages and their role in society. These dispositions may be largely unconscious and pre-rational because they are at the most fundamental level arguments about language. (Ruiz 1984: 16 [original emphasis])

Ruiz states that the three orientations can best be described as language-as-problem, language-as-right and language-as-resource (Ruiz 1984, 2010; Hult and Hornberger 2016).

The language-as-problem orientation-as the name suggests-is based on the claim that linguistic unity is desirable and minority languages are viewed as problems that are "standing in the way of the incorporation of members of linguistic minorities into the mainstream" (Hornberger 1990: 24). Bilingual education programmes may exist but they are treated with scepticism and they rarely lead to functional bilingualism (Hult and Hornberger 2016: 34).

The second orientation, language-as-right, is ideologically based on viewing language as a human right and seeks to legally secure that a specific language may be used in specific societal functions. However, implementation of rights in practice might be lacking since "there remains the possibility of covert resistance to those rights in practice" (Hult and Hornberger 2016: 37). It is also important to note that formulations relating to rights seek to secure a minority's right to do something as well as limiting what might be done to said minority.

Finally, language-as-resource is intended to represent the opposite of languageas-problem. This orientation has been somewhat criticized because it has been interpreted to promote language from a neo-liberal economic standpoint (c.f. Ricento 2005; Petrovic 2005). However, Ruiz emphasizes that language-as-resource includes 
both intrinsic value, such as "cultural reproduction, community relations, inter-generational communication, identity construction, building self-esteem and intellectual engagement" (Hult and Hornberger 2016: 39), as well as extrinsic value relating to economic and other marketable value. Ruiz also compares language-as-right and language-as-resource in order to exemplify that viewing a language as a resource means that the rights to use it are affirmed since "to say one's mother tongue is a linguistic human right - is to say, first, that the mother tongue is a good thing in itself" (Ruiz 2010: 165).

While Ruiz's orientations deal with the ideological underpinnings in different language policies, it does not deal with the issue of granted or denied access to what said policies seek to provide. Even the most generous of policies is rendered meaningless if it is not enforced in practice. I shall use Irvine and Gal's (1995) concept of erasure in order to describe discourses that surface when stakeholders seek to enrol to mother tongue instruction (MTI) in the aftermath of the closing of the Sweden Finnish independent school in Gothenburg (hence forth S-FG). Erasure is classified as a "process in which ideology, in simplifying the field of linguistic practices, renders some persons or activities or sociolinguistic phenomena invisible" (Gal and Irvine 1995: 974). Erasure may affect something completely, meaning that something is completely rendered invisible, or it may only affect parts so that something is only allowed to exist in certain contexts or functions.

I make use of Ruiz's orientations and implement them with critical discourse analysis $^{1}$ as an analytic tool. This allows me to examine how different policies that apply to the Swedish context and more specifically the Sweden Finnish minority's formal education context function in practice. I shall then examine local processes with the help of the concept of erasure.

\section{Data and method of analysis}

My data consists of language policy documents, interviews, media reporting as well as results from a recent special inquiry on minority language rights by the Swedish government (SOU 2017b: 91). I have analysed the data using critical discourse analysis with Ruiz's orientations as a stencil. Language policies steering the Sweden Finnish minority are three-fold consisting of supranational, national and local policies. The supranational policies are the Council of Europe's Framework Convention for the Protection of National Minorities, the European Charter for Regional or Minority Languages and UN's Convention on the Rights of the Child. The implementation and progress of language policy is monitored by respective organisation and they publish reports and critiques on possible misconducts and lack of action on the basis of the respective country's own reports and monitoring boards' visits to said countries. The national policy consists of Lag (2009: 724) om nationella minoriteter och minoritetsspråk [Law on national minorities and minority languages], Språklag (2009: 600) [Language Act], Skolförordning (2011: 185) [School

\footnotetext{
${ }^{1}$ I have opted to not associate with Critical language-policy research (CLP; e.g. Tollefson 2006), since my focus lies in language ideology rather than planning.
} 
ordinance] and Skollag (2010: 800) [Education Act]. Schools can be national and governed by the municipalities or independent schools that follow the national curriculum but can have for example a linguistic or religious profile. All of the abovementioned levels signal belonging to different orientations in varying degrees.

Ruiz's orientations can only provide a limited view on reality, since "in practice LPP is often shaped by an amalgamation of forces including extralinguistic social issues and political expediency" (Hult and Hornberger 2016: 42; Crawford 1998: 53). Therefore, besides examining supranational and national levels, I have analysed interviews with affected stakeholders in order to understand how the policies are implemented in practice.

The interviews were conducted in the spring of 2017 in person in Gothenburg and via telephone. The audio recordings of all conversations were transcribed while the interviews in Gothenburg were also filmed. Among the interviewees were a representative for the parents' association, children's parents and members of the school's support organisation board. The interviews were semi-structured and followed the same format. There has been limited interest among the affected parties to partake in interviews. Some people wanted to opt out giving the shock that the closing of the school resulted as grounds for not participating in the study. I also analyse media reporting around the issue, which has been vigorous in the minority public media.

\section{Analysis}

Different policies that affect the Swedish minorities and their language rights are analysed from the supranational level, followed by the national and the local level. Due to the ever-expanding body of language policy regulations the analysis will focus on excerpts and examples that overtly connect with Ruiz's orientations, rather than covering all of the material in minute detail.

\section{Supranational level}

The implementation of international agreements in Sweden follows a dualist model. It means that ratifying international agreement does not automatically turn said agreement into Swedish law as it would in a monist model (Bring et al. 2011: 42-53). In order to implement international agreements, they need to be incorporated into Swedish law. International agreements may be legalised by a process of incorporation or transformation:

International conventions are usually transformed into Swedish law by the enactment of equivalent provisions in an existing or a new Swedish statute. In certain cases, a convention can be incorporated by means of general law, stating that the convention shall apply in Sweden as Swedish law and be directly applicable. (UN General assembly 2010: II B 14)

The process of transforming an international policy into Swedish law entails that the original piece of legislation might be adopted in its entirety or in part, 
which might not lead to the desired result. Translating a supranational policy into a national language is also a factor that might alter the original text or allow new interpretations. The supranational policy texts that affect the Swedish policy are the Convention on the Rights of the Child (CRC 1990), the Framework Convention for the Protection of National Minorities European (Council of Europe 1998b; henceforth FCNM) and the European Charter for Regional or Minority Languages (Council of Europe 1998c; henceforth ECRML). I present the policies in the order of specificity starting with the most general.

The UN's convention's scope goes beyond securing minority language rights. Perhaps most importantly, article 28 paragraph 1 of the CRC decrees the child's right to education "on the basis of equal opportunity". When it comes to securing the child's linguistic rights the convention states that a child belonging to a minority "shall not be denied the right [...] to enjoy his or her own culture [...] or to use his or her own language" (CRC 1990: article 30 [emphasis added]) while "[s]tates Parties undertake to respect the right of the child to preserve his or her identity" (CRC 1990: article 8, 1 [emphasis added]). The state is also required to "[e]ncourage the mass media to have particular regard to the linguistic needs of the child" (CRC 1990: article 17, d). Finally, the convention states that education "shall be directed to [...] [t]he development of respect for the child's parents, his or her own cultural identity, language and values" (CRC 1990: article 29, c [emphasis added]). As seen above, by using phrases such as "shall not be denied the right" in article 30 the convention aims to limit discrimination towards children belonging to minorities rather than granting or demanding rights. However, as Skutnabb-Kangas and Dunbar (2010) note that the provision of article 30 of the CRC "echoes article 27 of the ICCPR" [International Covenant on Civil and Political Rights] and that "[...] [t]he Human Rights Committee, the treaty body created under the ICCPR, has, however, noted in its General Comment No. 23 (1994) on Article 27 [..] that, although phrased in the negative, the article requires States to take positive measures in support of minorities" (SkutnabbKangas and Dunbar 2010: 18).

Overall, the convention's formulations relate ideologically mostly to Ruiz's language-as-right orientation but its legal scope is limited because the convention is not embedded into Swedish law. However, after years of planning and negotiating, the convention will be made part of Swedish law in the beginning of January 2020 (Regeringskansliet 2018). The Council of Europe's FCNM (1998b) and ECRML (1998c) in the Swedish context are currently legally more significant, since they have been transformed into Swedish law.

Both the FCNM and ECRML consist of the policy itself but also explanatory reports that specify the requirements posited in the policies. The reasoning behind the explanatory reports is to guide and limit how the member states should and should not interpret the content. The implementation of both policies is also monitored. The monitoring bodies meet representatives of the speakers and authorities. Representatives for the minorities are also able to contact the Council of Europe and thus indirectly put pressure on the national level. This enables the Council of Europe to critique the member states on possible misconducts and provide suggestions for improvement. Thus far Sweden has been criticised nine times for not "not fulfilling 
its obligations in the educational field regarding national minority languages: three rounds from the FCNM and six from ECRML" (Lainio 2018: 58).

The formulations that reflect the ideological foundation of both the FCNM and ECRML are mostly found in the preambles of each policy and partly in their corresponding explanatory reports [ECRML explanatory report (1998a) and FCNM explanatory report 1998b]. The focus of the FCNM does not lie specifically on linguistic issues but rather on giving rights to minorities. With the FCNM the Council of Europe aims to "achieve greater unity between its members for the purpose of safeguarding and realising the ideals and principles which are their common heritage" and seeks to achieve this by a process of "maintenance and further realisation of human rights and fundamental freedoms" (FCNM 1998b: preamble). The preamble seeks to represent "cultural diversity to be a source and a factor [...] of enrichment for each society" and states that "pluralist and genuinely democratic society" should both respect and enable the national minorities to "express, preserve and develop" their identities and all related aspects, such as language (FCNM 1998b: preamble). The quotations from the FCNM clearly exhibit a multicultural ideology where minority identities are both a right and a resource.

However, the FCNM does briefly take linguistic aspects into consideration in Section II. It states that "[t]he Parties undertake to recognise that every person belonging to a national minority has the right to use freely and without interference his or her minority language, in private and in public, orally and in writing (article 10)" and that "every person belonging to a national minority has the right to learn his or her minority language" (FCNM 1998b: article 14, 1[emphasis added]). The second paragraph specifies that "the Parties shall endeavour to ensure" education in a minority language "as far as possible and within the framework of their education systems" if the language is spoken traditionally, if the language is spoken in substantial numbers and if there is sufficient demand (FCNM 1998b: article 14, 2). Skutnabb-Kangas and Dunbar point but that the inclusion of the above mentioned conditions is" most unfortunate, as the flexibility which it introduces can be misused" (Skutnabb-Kangas and Dunbar 2010: 24). The third paragraph concludes that the second paragraph "shall be implemented without prejudice to the learning of the official language or the teaching in this language" (FCNM 1998b: article 14, 3 ). Even other hedging exists in article 13, where paragraph 1 states that "persons belonging to a national minority have the right to set up and to manage their own private educational and training establishments" but specifies in the second paragraph that " $[\mathrm{t}]$ he exercise of this right shall not entail any financial obligation for the Parties" (FCNM 1998b: article 13, 1, 2). In this way, the states' commitments need only to remain on an ideological level.

For the most part the FCNM clearly connects with Ruiz's language-as-right orientation but it is debateable whether the policy offers more than its ideological declarations, especially when it comes to education. Dunbar discusses the apparent hedging in article 14 and concludes that the conditions that lessen the states obligation to article 14 "fundamentally compromise its effectiveness" (Dunbar 2001: 111). In sum, the reflected ideology in the FCNM relates mostly to the language-as-right orientation but is not strong enough to enact change. The FCNM is not the Council of Europe's main work of legislation that relates to minority 
languages. What the policy achieved was recognition and protection for national and regional minorities which can be seen as a precursor to a policy specifically covering minority languages. The ECRML seeks to serve this function.

The ECRML is significant since it is the only piece of international legislation that solely covers minority language policy. As with the FCNM the language ideological foundation of the ECRML is presented in the policy's preamble. The preamble coincides with several of Ruiz's orientations:

Considering that the protection of the historical regional or minority languages of Europe [...] contributes to the maintenance and development of Europe's cultural wealth and traditions; [...] Stressing the value of interculturalism and multilingualism. [...] Realising that the protection and promotion of regional or minority languages in the different countries and regions of Europe represent an important contribution to the building of a Europe based on the principles of democracy and cultural diversity. (ECRML 1998a: Preamble [emphasis added])

The quote connects with the language-as-resource orientation since it states that minority languages are something worth maintaining, i.e. having intrinsic value both for individuals and the surrounding society as well. Minority languages in the ECRML are classified as a "cultural wealth" (ECRML 1998a: Article 7, 1a) which according to Määttä diminishes the charter's impact: "[i]n other words, languages are not to be protected as such, rather, they are acknowledged as part of Europe's cultural heritage" (Määttä 2005: 171-172). Meanwhile, the extrinsic value related to the language-as-resource orientation is not represented, not even in article 13 which covers economic and social life (ECRML 1998a: article 13). Instead of promoting minority languages as e.g. assets on the labour market, the policy focuses on ensuring the right to use minority languages in economic and social life. In this regard the ECRML connects mostly with Ruiz's language-asright orientation.

Indeed, the ECRML's stance appears absolute by the excerpt stating that "the right to use a regional or minority language in private and public life is an inalienable right" (ECRML 1998a: preamble). However, as with the FCNM, it is debateable whether the policy is able to affect change on a national level and ensure the language rights as intended. Part three of the ECRML is divided into articles, which cover education, judicial authorities, administrative authorities and public services, media, cultural activities and facilities as well as economic and social life. Part three connects mostly with the language-as-right orientation and uses verbs such as encourage, foster, promote, take steps to ensure and allow (ECRML 1998a: Part III). Article 8 which covers education in and of minority languages seeks to make education available on all levels, or at least a substantial part of it (ECRML 1998a: article 8). I will discuss the parts that Sweden has chosen to ratify and the formulations when covering the national level. What is apparent is that these verbs are not exactly unambiguous and Määttä claims that the ECRML "as a whole is actually composed of principles rather than rules” (Määttä 2005: 173). I agree with Määttä to some extent but in my opinion the subparagraphs that aim to prevent discrimination against minorities and minority languages are composed more as rules which is 
reflected again in the verbs: eliminate, prohibit, and oppose (ECRML 1998a: Part III).

As presented, the requirements of each article and subparagraph differ in severity. More variety follows from the second subparagraph of article 2, which covers the so-called menu-system of the ECRML:

In respect of each language specified at the time of ratification, acceptance or approval, in accordance with Article 3, each Party undertakes to apply a minimum of thirty-five paragraphs or sub-paragraphs chosen from among the provisions of Part III of the Charter, including at least three chosen from each of the Articles 8 and 12 and one from each of the Articles 9, 10, 11 and 13 . (ECRML 1998a: article 2, 2)

Article 2, 2 allows members to choose paragraphs and sub-paragraphs, which means that the commitments between different members states may vary significantly depending on what they have ratified. Määttä claims that this allows member states to ratify paragraphs and subparagraphs that require "a minimum level of commitment to the protection of regional of minority languages" (Määttä 2005: 172).

As analysed above, the supranational policies connect to some degree with all of Ruiz's orientations but mostly with language-as-right. The policies seek to ensure access and rights to maintain and develop minority languages, i.e. to provide positive rights, as well prevent discrimination, i.e. provide negative rights. However, the way the policies are composed and how they are incorporated into domestic legislation may limit how successful the policies are at delivering said rights. This means that the supranational level of language policy cannot guarantee that minorities and their languages survive. Instead, the supranational level acts as a baseline or as Määttä describes the ECRML: it "is part of the creation of minimum legal standards for linguistic rights in Europe" (Määttä 2005:168 [emphasis added]). In this sense the supranational level is a perfect representation of what LHR aims to achieve. A too detailed policy would be difficult to ratify, not only because a detailed policy would most likely be in violation with various legal systems, as is the case with the ECRML in France (Määttä 2005: 179). However, the design of the ECRML's menu-system does usually allow states to choose parts that both serve the minority languages as well as fit the national legal systems. In dualist legal systems such as in Sweden the policies might be further modified when incorporated into national laws.

\section{National level}

The national legislation that relates to languages in Sweden is extensive and I will here cover the ones that affect minorities and minority language instruction, i.e. the Language Act (2009: 600), Law (2009: 724) on national minorities and minority languages (henceforth LONMM), Education Act (2010: 800) and the School ordinance (2011: 185). These policies combined cover both positive and negative rights of the minorities and govern everything from education to elderly care and where particular languages may be used. 
The Language Act is a fairly concise document of fifteen articles that describes the linguistic hierarchy in Sweden. First and foremost, it declares that Swedish is the main language in Sweden (Article 4) and that it is the shared language of society, which all inhabitants must have access to and must be able to use in all social functions (Article 5). According to the Language Act the public sector has a particular responsibility for the use and development of Swedish (article 6). In their discussion on Finnish and Swedish language policy Ihalainen and Saarinen state that "Swedish is discursively operationalised as the common language in Sweden rather than everyone's mother tongue" (Ihalainen and Saarinen 2015: 40). They also add that despite Sweden's attempt to appear open to multilingualism "the laws eventually tend to conserve the established [...] order and preserve societal cohesion rather than risk the emergence of linguistic disorder and discord" (Ihalainen and Saarinen 2015: 41).

The Language Act also declares that the minority languages of Sweden are Finnish, Yiddish, Meänkieli (or Tornedalian), Romany Chib and Sámi (article 7) and that in their case the public sector has a particular responsibility to protect and promote the national minority languages (article 8) which also applies to Swedish sign language (article 9). The Language Act specifies language use in judicial and international contexts, which is Swedish, while the law that applies to national minority languages can be found elsewhere (article 10). In the section on the "individuals' access to language" it is stated that"[a]ll residents of Sweden must be given the opportunity to learn, develop and use Swedish" (Language Act: article 14.1 [my translation]) while "persons belonging to a national minority are to be given the opportunity to learn, develop and use the minority language" (Language Act: article 14.1 [emphasis added, my translation]). The policy appears to follow the languageas-right orientation since it seeks to grant national minorities unequivocal rights and instruction of their languages as subjects. However, the policy does not specify in what form, to what extent and how the language will be taught and developed. Other policy documents are also written in a way that allows this uncontested position to be weakened. One of these documents is the Law on national minorities and minority languages (LONMM).

The LONMM specifies the articles of the Language Act but echoes also the ECRML, or rather, is the Swedish equivalent. As the ECRML, LONMM is, after the introduction, divided into sections that cover issues such as naming the administrative areas where the laws apply, reciting where and in which functions the minority languages may be used, which are administration, legal proceedings, education and elderly care as well as concluding remarks on how the law is to be monitored. The LONMM does not contain excerpts that would explain its views on multilingualism or on Sweden's national minorities, except adding to the Language Act's (article 8) formulation that the public sector has "a particular responsibility to promote the possibilities for the national minorities to preserve and develop their cultural identity and that children's development of a cultural identity and use of their own minority language should be promoted in particular" (LONMM: article 4 [my translation]). The most influential excerpt in the LONMM concerns pre-school education where it is stated that instruction should be provided "completely or partly in Finnish, Meänkieli or in Sámi” (LONMM: 
article 17). When compared with the paragraph 8.1.a.iii that Sweden has ratified of the ECRML, which demands that a substantial part or the entirety of instruction should be provided in the minority language to at least to those pupils whose families so request and whose number is considered sufficient (ECRML 1998a: article 8.1.a.iii), it becomes apparent that the Swedish law is weaker and allows minimal implementation. This is something that has been criticised before and there are attempts to change the formulation from partly into essential part (SOU 2017: 60: 28; Vuonokari and von Wright 2017 [my translation]). This would undoubtedly make the policy stronger but if such a change were to be implemented, whose definition of essential would it be based on?

The policies that actually govern education are the Education Act (2010: 800) and the School ordinance (2011: 185). Here I will only discuss issues with connection to minority languages and their relation to other subjects. Interestingly enough, articles that cover minority language instruction in the Education Act are few and far between. Most importantly, the policy states that "a pupil belonging to one of the national minorities must be provided with mother tongue instruction of the pupil's national minority language" (Education Act: chapter 10 article 7 [my translation]). This applies to all pupils regardless of their proficiency in the language and whether or not the language is spoken at home. The requirements for other mother tongues besides national minorities mandate that "the language must be the pupils daily language at home and that the pupil has basic proficiency in the language" (Ibid. [my translation]). According to the Education Act mother tongue instruction (hence forth MTI) in national minority languages should be provided without conditions on all levels, but what the Education Act does not specify is how many hours a pupil has the right to receive MTI, even though it does so for every other subject (Education Act: appendix 1). This has also been identified as a problem and there are ongoing attempts to rectify this issue (SOU: 2017: 91).

This means that the amount of instruction in a national minority language is a case by case negotiation and may vary from school to school, even within a single municipality. The School ordinance states in article 7 of chapter 5 that it is the principal of the school who decides on a pupil's MTI, but other actors within the municipality may be involved as well. In Sweden municipalities govern themselves and are in charge of a variety of issues, including education. (Regeringskansliet 2015). What the local governance enables to happen in practice is that MTI in national minority languages is guaranteed, but in some cases one person may decide the extent of the instruction and thus it is possible to be affected by personal ideologies. Even $15 \mathrm{~min}$ a week of instruction could then be seen as sufficient to fulfil the demands of the LONMM and the Education Act.

Finally, the School ordinance includes some parts that can be deemed as counterproductive. In fact, it is the only Swedish language policy that directly connects with the language-as-problem orientation. In article 9 of chapter 5 MTI, i.e. instruction in other languages than Swedish, is limited to one language per student, which means that officially the policy does not recognise a situation where a pupil might speak two languages other than Swedish at home, which in practice means that Sweden does not recognize multilingualism. If a pupil has a multilingual background she or he must choose which language to study. The result of such a choice might depend 
on factors that have nothing to do with preference towards a language, but rather what is available and qualitatively preferable.

Chapter 9 in the School ordinance contains an article relating to bilingual education which also connects with the language-as-problem orientation. According to article 13, the language of instruction may be a language other than Swedish maximally $50 \%$ of the total time of primary school education. It also states that the education must be structured so that instruction in Swedish increases successively. In practice, this means that minority language medium instruction starts off at $70 \%$ and decreases to $30 \%$ at the end of the ninth grade. What the article promotes, then, is what Skutnabb-Kangas and McCarty (2008) classify as a transitional late-exit programme. However, it is unclear how $70 \%$ in the first grade correspond with $70 \%$ in the ninth grade.

Despite the two instances above, the policies are mostly framed in a languageas-right manner and appear as a far more extensive set of rights beyond the LHR paradigm. However, the status of Swedish is ameliorated over everything else and this status is enforced by law. In order to find out whether the national policy is able to provide the minorities their linguistic rights I will next examine how they are implemented in practice on what I call the local level. I will focus on instruction of Finnish and I will provide examples from Gothenburg, where a bilingual Sweden Finnish independent school was closed abruptly in the middle of the 2016-17 academic year.

\section{Local level}

In this section I will examine how the national policy is enacted in practice nationally as well as locally in Gothenburg, in order to uncover which orientations are present. I will also examine how the notion of erasure could be seen in what followed after the closing of the S-FG.

The overall situation in Sweden on the local level can be characterised as presenting dual options. Pupils may receive Finnish instruction either in a school governed by the municipality usually as MTI, or in an independent school. Currently there are 5 independent Sweden Finnish schools in Sweden after one was closed by the Schools Inspectorate in Gothenburg in early January 2017. Gothenburg is the second-largest city of Sweden, situated in the South-West of Sweden. It has a population of 564,000 (Göteborgs stad 2017), of which approximately 30000 constitute the Sweden Finnish minority (Göteborgs stad, Stadsledningskontoret 2014: 11). Independent schools are governed either by a company, a foundation or an association, while the municipal schools are governed locally by the municipality (skolverket.se 2016). A pupil has the right to receive MTI as a subject in a municipal and an independent school. The instruction might differ both in extent and form depending on the municipality. Content-wise MTI is focused only on teaching the language and culture as a subject. However, a pupil studying in a Sweden Finnish independent school receives instruction not only in Finnish as a subject but other subjects through the medium of Finnish as well. The two different education systems operate under 
the same language policies and follow the Swedish curriculum, but they reflect different ideologies and thus lead to different outcomes.

The independent Sweden Finnish schools, which offer bilingual instruction through the medium of Finnish and Swedish, are by themselves a reaction to diminishing support from the municipalities from the late 1980s to the 1990s. Bilingual Finnish medium classes were abolished rapidly after the Swedish government announced its plans to cut funding for bilingual and L2 education (Lainio 1999: 151-152). From 1990 onwards, the number of pupils in bilingual education in municipal schools dropped from 4073 pupils to the current 40 pupils (SOU 2017: 91: 424). In a way, independent schools are by themselves an example of erasure, since after the bilingual classes in municipal schools ended the language was allowed to exist only marginally within the Swedish education system in the form of MTI. In this manner the language was not officially a part of the Swedish education system, but an anomaly sustained by the minority itself.

After the friskolereformen (prop. 1991/92: 95), i.e. the independent school reform, it became possible to open schools that were privately formed and governed. At the same time, it also became possible to freely choose which school to attend instead of a school being allocated based on its proximity. The independent schools "were entitled to have their own subject profiles, but had to follow the requirements of Swedish national curricula and be open to inspection by Swedish educational authorities" (Lainio 2015: 131). The formation of independent schools can be seen as melding together the LHR-paradigm and linguistic citizenship, since the minority exercised control over their language, albeit within the legal parameters.

The independent school system has been a subject of heated debate for a long time, where different stakeholders, politicians and researchers have voiced their opinions regarding this form of education. A report by the Swedish Research Council from 2014 features an overview of research results regarding independent schools and point out that independent schools have been deemed problematic since they might lead to competition between schools. This competition results in some schools becoming more desired than others which in turn might end up in socio-economic segregation (VR 2014: 100). In addition to this, schools with e.g. religious profiles are said to cause segregation and fail at promoting the values of the Swedish society (VR 2014: 39-40). Simultaneously the segregating effect has been questioned by some researchers who argue that residential segregation causes more educational segregation than freedom of choice or independent schools (Lindbom 2010: 626). Others have also advocated for independent schools stating that pupils attending independent schools with e.g. religious profiles may experience less bullying (VR 2014: 41). Contrary to the overall discourse on independent schools there is a consensus among national minorities that the independent education system is essential for keeping minority languages alive (SOU 2017: 91: 428). This does not mean that bilingual education options provided by the municipalities would be seen as negative. When asked, all informants from the former S-FG said they would place their children in bilingual education in a school governed by the municipality were such an option provided. Consequently, depending on only five remaining independent schools to provide bilingual education in the medium Finnish and Swedish in Sweden is fairly limiting. When also considering that not all of the remaining schools 
have a steady footing (SOU 2017: 91: 428-429) the situation is unstable to say the least.

The independent schools have operational freedom within the parameters of the national policy while also freely being able to shape their identities as a community. However, the freedom is somewhat problematic and could almost be classified as seclusion. The operational freedom is also partly restricted by the national policy. As mentioned before, independent schools, including the ones with Sweden Finnish profiles, are governed either by a company, a foundation or an association and they were mostly founded in the 1990s after the bilingual classes in municipal schools were shut down. This means that they were established because the public school system did not meet the demand for bilingual education. They had no aspirations for profit, nor of separation, since the bilingual capacity was seen as a prerequisite to preserve the heritage language and have the option of becoming integrated. The small and thus economically volatile independent schools operate on their own, which puts great pressure on the principals and the support boards for the schools to survive. If the school's is not managed to a well enough standard, the management is lacking in competence and problems persist it will be closed, which is what happened with the S-FG. Lahdenperä states that the principal of an independent school is burdened with a considerable amount of responsibility and needs to be knowledgeable, be able to lead efficiently but also be able to market the school for it to survive (Lahdenperä 2015: 99-100). In fact, Lahdenperä has argued that independent schools - in order to avoid these problems - should be governed by the state in order to guarantee their survival (Laitinen 2017). In the case of the Sweden Finnish school in Gothenburg the principal and the support board were unable to comply with all of the school inspectorate's demands, and according to my interviews the parents and the parents' association were uninformed about the school's predicament before it was too late. This exemplifies both the volatility and the responsibility that the school's organisation has.

The volatility of independent schools becomes a matter of greater concern when they are forced to compete with municipal schools. In fact, during my interview with the former head of the financial organisation for the S-FG it became clear that some of the positive language policy developments in Sweden were actually working against the Sweden Finnish school. The municipality's primary schools had started to provide instruction in the subject of Finnish and partly Finnish medium teaching which created economic rivalry between the municipality's school and the independent school. The former head of the financial organisation states that losing students to the municipality's schools was an economic setback since the school, as all independent schools, was funded per pupil. According to Lahdenperä, independent schools are generally considered competing with municipal schools (Lahdenperä 2015: 95). Lahdenperä states further that the playing field between the two systems is uneven since neither the school's leadership nor its staff receive further education and competence development from the municipality (Ibid.) despite the fact that such schools are publicly funded. These examples exhibit the manner in which local actions might distort granted positive rights into impeding the group that should benefit from the policy. 
Since the independent Sweden Finnish schools follow the national curricula as do the municipal schools, they are subject to the problematic policy choices that were presented in the section for the national level, e.g. limiting pupils from choosing instruction in another mother tongue in addition to Finnish. Beyond this, the schools are required to follow the School ordinance's rule by which instruction in Finnish, or any language other than Swedish, cannot exceed 50\% during primary school. Not following the rule was one of the issues for which the Schools Inspectorate criticised the S-FG; the document stated multiple times that the pupils did not receive instruction through the medium of Swedish the amount they "had the right to" (Skolinspektionen 2016a: 10). However, adhering to this rule in practice is more difficult than it might appear since, according to my informants, some of the classes in the former Sweden Finnish school were shared with different grades which makes the process of counting hours and therefore the percentage difficult.

Despite the $50 \%$ rule the independent schools indisputably connect with Ruiz's language-as-resource orientation. The independent schools themselves are not only concrete examples of intrinsically valuing Finnish as a minority language but also valuing the language extrinsically by employing teachers who speak Finnish and promoting e.g. cultural events by Sweden Finnish NGOs. All of the interviewed parents, including the head of the former parent's association of the now closed Sweden Finnish school, viewed the bilingual instruction as excellent. However, the independent schools are volatile and are able to provide education to fairly limited groups of pupils. They are also required to compete with the municipal schools and represent a form of education that is under heated debate but for other reasons than for their educational, bilingual profile. Therefore, the independent education sector faces an uphill climb.

When viewing the independent schooling system's counterpart and currently the only option for instruction of Finnish in Gothenburg, i.e. MTI, it becomes evident that the implementation of the national language policy does not achieve the goals that characterise the language-as-right orientation. In fact, the local implementation follows most of the characteristics of the language-as-problem orientation while, oddly enough, still managing to blatantly avoid breaching any particular article of the national policy. In other words, the language-as-right orientation is transformed into the language-as-problem orientation due to lack of cooperation, disinterest, conflicting claims and limited resources (see further below). Most of the reported processes connect with Irvine and Gal's notion of erasure.

The process of applying for MTI in Finnish in the municipality's schools was described as lengthy and difficult. According to my informants the schools were largely unaware of their legal obligations and the parents were forced to inform the municipal school administrators of the minority language rights even though it is legally mandated $\$ 3$ in LONMM to inform the minority of their rights (Sveriges riksdag 2009a). Enrolment problems seemed to persist even in the beginning of the autumn term of 2017, 6 months after the closing of the independent school. This phenomenon is not limited to Gothenburg since it has been acknowledged as a nationwide problem (SOU 2017: 91: 242-243). Not being able to register for MTI may have severe long-lasting consequences. 
The number of registered pupils in Finnish MTI has become important, since, according to my informants, the municipality has set it as a precondition for extending and further developing MTI or some other form of instruction in Finnish. The municipal school Commissioner of the city of Gothenburg has repeatedly claimed that "the municipality cannot operate empty schools" (Karlsson and Hoppu 2017). Such comments convey that minority language education is seen as an economic burden by the municipality without its intrinsic value, which connects directly to the language-as-problem orientation. Belittling the existence of the minority is also an example of erasure. The school commissioner doubts that there are enough pupils for bilingual education or even MTI, despite the fact that the city's own action plan for the Sweden Finnish minority from 2014 states that the number of young Finnish speakers under the age 19 in Gothenburg is approximately 10.000 out of which 350 receive instruction of Finnish in some form (Göteborg 2014: 12). What these numbers indicate is that information for MTI is lacking, not that the minority is small.

After the S-FG closed it appeared to be unclear who was responsible for deciding the amount of instruction of teaching offered. As it is now, the maximum amount of instruction of Finnish in a municipal school is 80 min per week, but it may vary (Karlsson and Hoppu 2017). In a broadcasted radio debate, the operations manager for the language centre, which e.g. supplies mother tongue instructors to schools, states that the principals of schools decide to what extent MTI will be provided in municipal schools. However, the head of the parents' association says this conflicts with the principals' claim that the municipality is the authority in the matter. Meanwhile the municipal school Commissioner states that it is for the city's districts to decide if the schools want to provide more instruction than the "mandated $80 \mathrm{~min}$ " (Karlsson and Hoppu 2017 [my translation]). However, beginning in 2018 the districts will no longer be in charge of mandating this since the task will be centralised to the municipality (Starckman 2017). The municipal school Commissioner's answer to the question, whether she thinks 80 min per week is enough to fulfil the particular responsibility of promoting and preserving the minority children's linguistic development, mandated by the LONMM, was "I am no expert" (Karlsson and Hoppu 2017 [my translation]). Be as it may, 80 min a week cannot be considered sufficient for language maintenance, not to mention development and thus aims "at transition to the dominant language" (Hult and Hornberger 2016: 33). In his report for the Swedish government Lainio discovered that the situation in Gothenburg is not unique:

On average, one hour of teaching is offered per week. This is not sufficient for a planned and perceptible progression in the learning of these languages. There has been a detrimental impact on the demand for this teaching and likewise on the status of its teachers. (SOU 2017: 91: 40)

The low amount of teaching of Finnish offered was not the only problem in MTI classes. According to my informants the pupils in MTI classes are not differentiated well enough within the group. Instead, all students who have applied for MTI in Finnish in a particular school follow the same classes regardless of proficiency or age. After the pupils of the former S-FG, who speak the language well, were transferred into municipal schools and have joined classes with complete beginners. 
Because of this, several of the interviewed parents expressed their concern that the classes would not be able to serve any of the pupils. A factor that complicates the issue further is that there are currently only two Finnish teachers employed in the municipality. According to the head of the parents' association the teachers need to travel weekly between as many as eleven schools each, which reduces the teachers' preparation time and also influences their possibilities to build a relationship with their pupils. Again, these observations are in line with the situation in Sweden as a whole (SOU 2017: 91: 338). Finally, by not interacting in a bilingual environment, if compared to the situation in a bilingual independent school, the pupils are most likely not going to interact by using Finnish bur rather retract to using only Swedish. In fact, some pupils have reported that four different teachers have denied the pupils from talking Finnish amongst each other (Hoppu 2017). This is a clear case of erasure, where the language is completely denied visibility outside of the MTI classes.

As stated above, the municipal option of Finnish instruction seems to be suffering from structural problems and little progress seems to have been made. The involved parties from the municipality's and the schools' side seem to view Finnish MTI negatively and their apparent unwillingness to act is constructed as a discourse of inability combined with erasure. The municipality adheres to arbitrary self-invented guidelines such as the 80 min per week limitation on teaching and not differentiating pupils according to their proficiency. At the same time different actors seem to shift blame from one another and progress is slow. In sum, it is safe to state that the national policy in itself does not relate to the language-as-problem category but does not provide strong enough support for it to prevent local policies from freely contradicting the national policy. In its current state the national policy translates into minimal support for the minority language. Instead of fulfilling their commitments towards the national minority language, Finnish is currently allowed only to exist in MTI classes with heterogeneous groups, not providing with enough teaching time and having few teachers.

\section{Discussion}

As my analysis illustrates, the language policy in Sweden is multifaceted and operates on different levels. The main body of language policy mostly follows the statecontrolled paradigm of linguistic human rights. The supranational policy does not directly affect Swedish policy unless it is incorporated into Swedish law. However, since the supranational governing bodies include an ongoing monitoring and evaluation process, minorities themselves are able to be in contact with e.g. the Council of Europe and thus indirectly put pressure on the national government. Whether the Swedish government reacts to criticism and to what degree is another matter. In the beginning, I set out to examine (1) how supranational, national and local language policies connect with Ruiz's orientations and (2) whether these orientations are reflected in the implementation of the policies. It is clear that both the supranational and the national levels exhibit similar tendencies when analysed with Ruiz's orientations in mind, though with minor differences. The policies on both levels declare to value different languages (language-as-resource), while also seeking to 
secure the minorities' rights to maintain and develop their languages and identities (language-as-right).

Sweden's efforts to secure minority rights on a national level cannot be questioned when examining the existing and recent developments in legislation and e.g. by restarting teacher education at universities. In other words, the ideology towards minorities cannot be overtly negative if there is a support mechanism in place. It is worth to note that some elements of national policy are in clear contradiction with the displayed ideology, e.g. the $50 \%$ rule (School ordinance: chapter 9 article 13), as well as the restriction that a pupil may receive instruction in only one mother tongue (School ordinance: chapter 5 article 9). However, the question remains; if the supranational and national levels ideologically support and improve the minority language's possibilities to thrive, why does e.g. the Sweden Finnish minority in Gothenburg feel that their linguistic rights are not being met? Since the policies are not intrinsically the issue, the problems mainly become evident on the local level. The case in Gothenburg exemplifies this well.

Despite having applied to become an administrative area for the Sweden Finnish minority, Gothenburg provides the bare minimum for the minority, especially when it comes to the issue of education. As long as the S-FG provided bilingual Finnish medium education the minority seemed to sustain itself, but once the school was shut down and the municipality was forced to take over, the problems started to surface. Despite multiple talks with the affected parties the municipality seemed to be unaware of their legally mandated responsibilities, especially when it came to inform the minority about their rights. The minority also brought up issues such as heterogeneous groups, lacking teaching staff and insufficient teaching times, without getting support from the municipality. This situation — despite its high level of urgency-is not in direct violation with national policy as such. The municipality interprets the policy in a way that results in providing minimal instruction in Finnish. Not providing sufficient instruction can thus be seen as an ideological statement about the perceived value of the Sweden Finnish minority and Finnish, in Gothenburg.

The results of the Swedish government's special inquiry point to the fact that the situation in Gothenburg is not unique. In order to remedy this the inquiry proposes that instead of MTI, the five national minority languages should be subjects in themselves with a legally mandated amount of teaching, which would mean that there would be more demand for teachers, the status of the languages would improve, and the structure would be clearer (SOU 2017: 91: 38-43). Such a policy change would also help pupils to be able to continue their studies on the upper secondary level and possibly at university level. However, it is unclear whether the proposals will become a reality. Language policy, especially when it comes to securing the rights of minorities can be identified to take place in several phases. The Sweden Finnish minority can currently be said to be stalled in what Hornberger (2006) calls the status planning phase. If the Sweden Finnish minority is to remain vibrant in Gothenburg, the municipality will need to increase MTI in schools and differentiate the pupils according to their proficiency, before the current generation experiences a final language shift. 


\section{Conclusion}

In my view Richard Ruiz's claim that language policy reflects fundamental arguments about language is certainly true for the most part. However, Ruiz's orientations do not take into account the implementation of said policies. Policies by themselves are meaningless if they are not enacted. Therefore, it is equally important to examine implementation processes and instances where access to granted rights are denied. Irvine \& Gal's notion of erasure is one useful concept when examining the rhetoric of those who implement policies. The application of Richard Ruiz's orientations to language policy in a Swedish context revealed that ideologies of and toward languages are undoubtedly governed from a top-down trajectory and they function as a kind of national identity for the outside world. However, if erasure and local opposing practises still manage to reign free, the national policy and monitoring systems cannot be deemed as sufficient.

Funding This study is a part of Lasse Vuorsola's Ph.D. thesis and was funded by Stockholm University.

\section{Compliance with ethical standards}

Conflict of interest Vuorsola's Ph.D. supervisors are Professors Jarmo Lainio and Päivi Juvonen. The article is partly written for a course and the course instructors are Professors Caroline Kerfoot, Maria Kuteeva and Christopher Stroud.

Informed consent Informed consent was obtained from all individual participants included in the study.

Open Access This article is distributed under the terms of the Creative Commons Attribution 4.0 International License (http://creativecommons.org/licenses/by/4.0/), which permits unrestricted use, distribution, and reproduction in any medium, provided you give appropriate credit to the original author(s) and the source, provide a link to the Creative Commons license, and indicate if changes were made.

\section{References}

Bring, O., Mahmoudi, S., \& Wrange, P. (2011). Sverige och folkrätten (4th ed.). Stockholm: Norstedts juridik.

Burr, V. (2015). Social constructionism (3rd ed.). London: Routledge.

Council of Europe (CoE). (1998a). Explanatory report to the European charter for regional or minority languages. https://rm.coe.int/16800cb5e5. Accessed 22 August 2018.

Council of Europe (CoE). (1998b). European Charter for Regional or Minority Languages (ECRML). https://rm.coe.int/CoERMPublicCommonSearchServices/DisplayDCTMContent?documentId $=0900001680695175$. Accessed 22 August 2018 .

Council of Europe (CoE). (1998c). Framework convention for the protection of national minorities and explanatory report (FCNM). https://rm.coe.int/16800c10cf. Accessed 22 August 2018.

Crawford, J. (1998). Language politics in the U.S.A.: The paradox of bilingual education. Social Justice, 25(3), 50-69.

CRC. (1990). Convention on the rights of the child. https://www.ohchr.org/EN/ProfessionalInterest/Pages /CRC.aspx. Accessed 22 August 2018.

Dunbar, R. (2001). Minority language rights in international law. International and Comparative Law Quarterly, 50, 99-120.

Foucault, M. (1972). The archaeology of knowledge and the discourse on language. New York: Pantheon Books. 
Gal, S., \& Irvine, J. T. (1995). The boundaries of languages and disciplines: How ideologies construct difference. Social Research, 62(4), 967-1001.

Göteborgs stad. Stadsledningskontoret. (2014). Handlingsplan för finskt förvaltningsområde. http://goteb org.se/wps/wcm/connect/53800688-6091-4b62-9fcc-10b9798cc176/Handlingsplan+finskt+forva ltningsomrade.pdf?MOD=AJPERES. Accessed 22 August 2018.

Göteborgs stad. (2017). Statistik. http://statistik.goteborg.se/. Accessed 22 August 2018.

Hoppu, L. (2017). Göteborgilaiskoulun oppilaat: 'Meitä on kielletty puhumasta suomea'. Sveriges radio. https://sverigesradio.se/sida/artikel.aspx?programid=185\&artikel=6817961. Accessed 22 August 2018.

Hornberger, N. H. (1990). Bilingual education and English only: A language-planning framework. The Annals of the American Academy of Political and Social Science, 508, 12-26.

Hornberger, N. H. (2006). Frameworks and models in language policy and planning. In T. Ricento (Ed.), An introduction to language policy Theory and method. Malden: Blackwell Publishing.

Hult, F., \& Hornberger, N. H. (2016). Revisiting orientations in language planning: Problem, right, and resource as an analytical heuristic. Bilingual Review, 33, 30-49.

Huss, L., \& Spiliopoulou, S. (2005). Minoritetsspråkens ställning i Sverige. In L. Huss \& A. R. Lindgren (Eds.), Rätten till eget språk. Oikeus omaan kieleen. Språklig emancipation i Finland och Sverige. Uppsala: Centrum för multietnisk forskning.

Hyltenstam, K., \& Tuomela, V. (1996). Hemspråksundervisningen. In K. Hyltenstam (Ed.), Tvåspråkighet med förhinder? Invandrar- och minoritetsundervisning i Sverige. Lund: Studentlitteratur.

Ihalainen, P., \& Saarinen, T. (2015). Constructing 'Language' in Language policy discourse: Finnish and Swedish legislative processes in the 2000s. In M. Halonen, P. Ihalainen, \& T. Saarinen (Eds.), Language policies in Finland and Sweden. Interdisciplinary and multi-sited comparisons. Bristol: Multilingual Matters.

Karlsson, V. \& Hoppu, L. (2017). Debatti: Miten käy suomenkielisen opetuksen Göteborgissa? Sveriges radio, Sisuradio. http://sverigesradio.se/sida/artikel.aspx ?programid=185\&artikel=6610221. Accessed 22 August 2018.

Lahdenperä, P. (2015). Skolledarskap i mångfald. Lund: Studentlitteratur.

Lainio, J. (1999). Språk, genetik och geografii-om kontinuitetproblematiken och debatten om finska som minoritetsspråk. In K. Hyltenstam (Ed.), Sveriges sju inhemska språk. Lund: Studentlitteratur.

Lainio, J. (2001). Protection and rejection of minority majority languages in the Swedish system. Current Issues in Language and Society, 7(1), 32-50.

Lainio, J. (2015). The art of societal ambivalence: A retrospective view on Swedish language policies for Finnish in Sweden. In M. Halonen, P. Ihalainen, \& T. Saarinen (Eds.), Language policies in Finland and Sweden. Interdisciplinary and multi-sited comparisons. Bristol: Multilingual Matters.

Lainio, J. (2018). The five national minorities in Sweden and their languages The state of the art and ongoing trends. In N. E. Forsgård \& L. Markelin (Eds.), Perspectives on minorities in the Baltic Sea area. Helsinki: Magma.

Laitinen, M. (2017). Professori: Ruotsinsuomalaiset koulut olisi paras siirtää valtion vastuulle. Sveriges radio, Sisuradio. http://sverigesradio.se/sida/artikel.aspx ?programid=185\&artikel=6614461. Accessed 22 August 2018.

Lindbom, A. (2010). School choice in Sweden: Effects on student performance, school costs, and segregation. Scandinavian Journal of Educational Research, 54(6), 615-630.

Määttä, S. K. (2005). The European charter for regional or minority languages, French language laws, and national identity. Language Policy, 4, 167-186.

Petrovic, J. E. (2005). The conservative restoration and neoliberal defences of bilingual education. Language Policy, 4, 395-416.

Regeringskansliet. (2015). Den lokala nivån-kommuner. https://www.regeringen.se/sa-styrs-sverige/detdemokratiska-systemet-i-sverige/den-lokala-nivan-kommuner/. Accessed 22 August 2018.

Regeringskansliet. (2018). Barnkonventionen blir svensk lag. https://www.regeringen.se/regeringen s-politik/barnkonventionens-vag-mot-svensk-lag/. Accessed 22 August 2018.

Ricento, T. (2005). Problems with the 'language-as-resource' discourse in the promotion of heritage languages in the U.S.A. Journal of Sociolinguistics, 9(3), 348-368.

Ruiz, R. (1984). Orientations in language planning. NABE Journal, 8(2), 15-34.

Ruiz, R. (2010). Reorienting language-as-resource. In J. Petrovic (Ed.), International perspectives on bilingual education: Policy, practice and controversy. Charlotte: Information Age Publishing. 
Skolinspektionen. (2015). The Swedish schools inspectorate for international audiences. https://www. skolinspektionen.se/globalassets/0-si/09-sprak/the-swedish-schools-inspectorate.pdf. Accessed 22 August 2018.

Skolinspektionen. (2016a). Beslut för förskoleklass och grundskola efter tillsyn av Sverigefinska skolan $i$ Göteborg belägen $i$ Göteborgs kommun (44-2015:4266). http://siris.skolverket.se/siris/ris.openf ile?docID=553252. Accessed 22 August 2018.

Skolinspektionen. (2016b). Återkallelse av godkännande efter tillsyn av Sverigefinska skolan $i$ Göteborg belägen i Göteborgs kommun (44-2015:240). http://siris.skolverket.se/siris/ris.openfile?docID $=561206$. Accessed 22 August 2018.

Skolverket.se. (2016). Grundskola. https://www.skolverket.se/skolformer/grundskoleutbildning/grund skola. Accessed 22 August 2018.

Skutnabb-Kangas, T. (2006). Language policy and linguistic human rights. In T. Ricento (Ed.), An introduction to language policy. Theory and method. Malden: Blackwell Publishing.

Skutnabb-Kangas, T. \& Dunbar, R. (2010). Indigenous children's education as linguistic genocide and a crime against humanity? A global view. In Gáldu Čála. Journal of Indigenous Peoples' Rights, No 1. Guovdageaidnu/Kautokeino: Galdu, Resource Centre for the Rights of Indigenous Peoples.

Skutnabb-Kangas, T., \& McCarty, T. (2008). Clarification, ideological/epistemological underpinnings and implications of some concepts in bilingual education. In J. Cummins \& N. H. Hornberger (Eds.), Encyclopedia of language and education, bilingual education (2nd ed., Vol. 5, pp. 3-17). New York: Springer.

SOU 2017:60. Rhodin, L., Mlayeh, S. \& Lantz, J. Nästa steg? Förslag för en stärkt minoritetspolitik. Statens offentliga utredningar. Regeringskansliet. http://www.regeringen.se/49d73d/contentassets/ f869b8aae642474db1528c4da4d2b19a/nasta-steg-forslag-for-en-starkt-minoritetspolitik-sou-20176 0. Accessed 22 August 2018.

SOU 2017:91. Lainio, J. (2017). Nationella minoritetsspråk i skolan-förbättrade förutsättningar till undervisning och revitalisering. Betänkande av utredningen om förbättrade möjligheter för elever att utveckla sitt nationella minoritetsspråk. Regeringskansliet.

Starckman, A. (2017). Göteborg selvittää kaksikielisen opetuksen järjestämistä. SVT Nyheter, Uutiset. https://www.svt.se/nyheter/uutiset/goteborg-selvittaa-kaksikielisen-opetuksen-jarjestamista. Accessed 22 August 2018.

Stroud, C. (2001). African mother-tongue programmes and the politics of language: Linguistic citizenship versus linguistic human rights. Journal of Multilingual and Multicultural Development, 22(4), 335-339.

Sveriges riksdag. (2009a). Lag (2009:724) om nationella minoriteter och minoritetsspråk [Law on National Minorities and Minority Languages]. http://www.riksdagen.se/sv/dokument-lagar/dokum ent/svensk-forfattningssamling/lag-2009724-om-nationella-minoriteter-och_sfs-2009-724. Accessed 22 August 2018.

Sveriges riksdag. (2009b). Språklag (2009:600) [Language Act]. http://www.riksdagen.se/sv/dokumentlagar/dokument/svensk-forfattningssamling/spraklag-2009600_sfs-2009-600. Accessed 22 August 2018.

Sveriges riksdag. (2010a). Skollag (2010:800) [Education Act]. http://www.riksdagen.se/sv/dokumentlagar/dokument/svensk-forfattningssamling/skollag-2010800_sfs-2010-800. Accessed 22 August 2018.

Sveriges riksdag. (2010b). Skolförordning (2011:185) [School Ordinance]. https://www.riksdagen.se/ sv/dokument-lagar/dokument/svensk-forfattningssamling/skolforordning-2011185_sfs-2011-185. Accessed 22 August 2018.

Tollefson, J. W. (2006). Critical theory in language policy. In T. Ricento (Ed.), An introduction to language policy. Theory and method. Malden: Blackwell Publishing.

UN General Assembly. Human Rights Council. (2010). National report submitted in accordance with paragraph 15 (a) of the annex to Human Rights Council resolution 5/1. http://www.manskligarattig heter.se/dm3/file_archive/100518/e6cd45dd15b6e84cb925e6669b9ee9a6/National\%20UPR\%20rep ort\%20eng.pdf. Accessed 22 August 2018.

VR. (2014). Barns och ungas utbildning i ett segregerat samhälle. Mångfald och migration $i$ valfrihetens skola. Vetenskapsrådet.

Vuonokari, K \& von Wright, E. (2017). Regeringens utredare Lennart Rohdin: 'Så här får vi kommunerna att lyda minoritetslagen'. Sveriges radio, Sisuradio. http://sverigesradio.se/sida/artikel.aspx?progr amid=185\&artikel=6664356. Accessed 22 August 2018. 
Lasse Vuorsola is a doctoral candidate studying at the Finnish section at Stockholm University. His research interests include sociolinguistics, interactional sociolinguistics, language policy, nexus analysis as well as critical discourse analysis. 